洞不全症候群の薬理学的自律神経遮断の過程に括ける心拍数の変動 老年と若年の差異

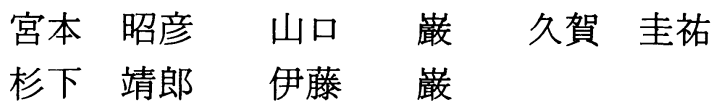

\begin{abstract}
<要 約> 各年齢層の洞不全症候群 (SSS) 患者に対する薬理学的自律神経遮断 (TAB) の全過程に おいて，実測固有心拍数 (IHRo) 異常群とIHRo 正常群の間で，1）加齢による变化と，2）自律神経の 関与に対する反応の差異について検討した.

16歳から72歳の SSS 患者35例（男21例, 女14例, 平均年歯50歳）を対象に, 安静時心周期 (BCL) 測 定後, atropine sulfate $0.04 \mathrm{mg} / \mathrm{kg}$ の 2 分間の静注において30秒毎および5分後と，それに引き続く propranolol $0.2 \mathrm{mg} / \mathrm{kg}$ 静注（静注速度 $1 \mathrm{mg} /$ 分）において，5，8，10分および静注終了時（IHRo 決定時） の心周期 $(\mathrm{CL})$ を測定した。 各症例の予測固有心拍数（IHRp=118.1-0.57×年齢）を求めて, IHRp の下限以上を正常群，それ未満を異常群とし，さらに60歳以上と未満とに分類した。

これらの成績として次の結論が得られた１）BCL は異常 IHRo 群が正常 IHRo 群より有意に大であ $\eta(60$ 歳以上群 $; \mathrm{p}<0.05,60$ 歳未満群 $; \mathrm{p}<0.01)$, 自律神経によって代償されえない洞結節機能障害の 存在が示唆された。2）atropine sulfate 静注後の CL が IHRpCLの上限よりも大であることは異常 IHRo 群に特異的であるが，一方， atropine sulfate 静注のみでは異常 IHRo 群の一部が正常と判定され る可能性がある. 3）異常 IHRo 群および正常 IHRo 群において, 60歳未満群は副交感神経優位の傾向を 示し，特に異常 IHRo を示す60歳未満群においては，副交感神経による negative chronotropy を最も強 く受けていると考兄られた。 4) atropine sulfate 静注後よりIHRo 決定時に至る過程において，正常 IHRo 群には年㱓による差異は認められなかったが, 異常 IHRo 群では60歳以上群において, CL の有意 の延長が認められた．5）propranolol 静注に対する反応に関して，異常 IHRo 群では，交感神経による positive chronotropy はCL の正常上限境界に打ける critical な要因と考兄られた。
\end{abstract}

Key words：洞不全症候群, 薬理学的自律神経遮断, アトロピン, プロプラノロール, 加齢

\section{緒言}

1978年, Jordan $ら^{1)}$ は薬理学的自律神経遮断(TAB) による実測固有心拍数 (IHRo) を用いて洞不全症候群 （SSS）の病態生理学的分類を行った。しかし TABの 全過程に颃いて異常 IHRo 群ならびに正常 IHRo 群 の自律神経の影響を検討した報告はなく,さらに, SSS に抢ける洞結節機能の加齢に伴う变化についての報告 は少な(2) 5).

本研究の目的は, 種々の年齢層の SSS 患者に対する TAB の過程に打いて, 異常 IHRo 群と正常 IHRo 群 との間で, 1) 加齢による変化, と2）自律神経の関与

A. Miyamoto, I. Yamaguchi, K.Kuga, Y. Sugishita,

I. Ito：筑波大学臨床医学系内科

受付日. 1988. 10．5：採用日. 1989. 1， 19 .
に対する反応の差異について検討することにある.

\section{対象と方法}

50心拍/分以下の洞性徐脈と中权神経症状の関連が 確認された SSS 患者35例(男21例，女14例，50土21歳， mean \pm SD)を対象とした。標準12誘導心電図, Holter 心電図あるいはモニター心電図に洞停止が 6 例, 洞房 ブロックが 4 例, 徐脈頻脈症候群が 3 例確認されてい たが，すべての症例に，本研究の過程でそれらの不整 脈は認められなかった。 atropine sulfateあるいは propranolol 静注により，接合部調律あるいは接合部 補充調律が出現した症例は対象から除外した。洞結節 機能および自律神経に影響を与えると思われる薬剤は 検査の48時間前に中止した。

電気生理学的検査：文書で患者の承諾を得た後, 標 
準心内心電図記録法を用いて心腔内電位（高位右房, His 束，右心室心尖部)を体表面心電図 (I, aVF, V1) と同時に, 紙送り速度 $100 \mathrm{~mm} / \mathrm{sec}$ で記録した（E for $\mathrm{M}, \mathrm{VR} 12)$.

1）心周期の測定：(1) 安静時心周期測定, (2) atropine sulfate $0.04 \mathrm{mg} / \mathrm{kg}$ (A)の 2 分間の静注にお いて, 静注開始後 30 秒， 60 秒，90秒，120秒(静注終了) および 5 分後と，それに引き続いて，(3）propranolol $0.2 \mathrm{mg} / \mathrm{kg}(\mathrm{P})$ （静注速度 $1 \mathrm{mg} /$ 分）静注において，静 注開始後 5 分, 8 分, 10 分拉よび静注終了時(IHRo 決 定的）のそれぞれ10心拍の洞調律心周期の平均値を算 出した。

2) 予測固有心拍数 (IHRp) の算出: IHRp= $118.1-0.57 \times$ 年齢の式で求め, 45 歳末満はIHRo の $\pm 14 \% ， 45$ 歳以上は $\pm 18 \%$ 以内を正常值とする Jordan $ら^{11}$ の方法に従って, 各症例の IHRp の下限以上 は正常, IHRp の下限未満は異常と定義して, それぞれ IHRo 正常群 (I 群) および IHRo 異常群 (II群) とし た。さらにそれぞれの群において60歳未満（Y 群）と 60 歳以上 ( $\mathrm{E}$ 群) に分類した。

本研究においては安静時心拍数および $\mathrm{TAB}$ 後の固 有心拍数などの測定値はすべて心周期 (CL : msec) に 換算して mean $\pm \mathrm{SD}$ で表示した。平均值の差の検定に はStudent の $\mathrm{t}$ 検定ならびに百分率の比較にはカイ二 乗検定を用いた。

\section{結 果}

1) SSS 35例は TABによって I 群21例(IY 群14例, IE 群 7 例) と II 群13例（IIY 群 8 例, IIE 群 5 例) に分 類された。IY 群に女性が多い傾向が見られたが有意差 は認められなかった。

I 群ならびにII 群の安静時と atropine おょび propranolol 静注による TAB までの全過程を図 1 および 表 1 と示す。

2）安静時心周期 (BCL) は, IY 群が912 $195 \mathrm{msec}$,

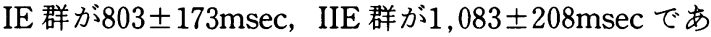
り，いずれも正常値を示したが, IIY 群は $1,216 \pm 243$ msec であり，正常 IHRp の洞周期より延長を示した。 IY 群と IE 群, IIY 群と IIE 群との間には有意差が認 められなかったが, IY 群は IIY 群より, IE 群は IIE 群 より有意に小であった（それぞれ $\mathrm{p}<0.01, \mathrm{p}<0.05$ ， 表 2 ), IY 群の 14 例中 2 例, IE 群の 7 例中 6 例, IIE 群 の 6 例中 1 例に抢いて心周期は Jordan ら 従って求めた IHRp の正常下限に対応する心拍数（以
下，IHRp の最大値とする)より小であった．IIY 群に おいては，全例の BCL が IHRpCL の最大值よりも大 であった。

3）A 静注過程における CL の平均值は，I 群のらち IY 群では進行性に短縮を示し，BCL との比較に打い て静注開始後 30 秒と60秒では有意差がなかったが，90 秒, 120 秒および 5 分後においては, 有意差が生じた(い ずれも $\mathrm{p}<0.001)$. IE 群でも同様に静注開始後 120 秒 および 5 分後に打いて有意差が生じた（いずれも $\mathrm{p}<$ 0.01). IY 群と IE 群の間には，BCL 測定時から A 静 注過程のいずれの時点にも有意差は認められなかっ た.IY 群では静注開始後 120 秒においては，2 例を除く 12例の CL が IHRpCL の最大值より小となり，5 分後 には全例が小となった. IE 群においては静注開始後30 秒，60秒，90秒に 1 例を除く 6 例の CL が，120秒扰よ び 5 分後に全例の CL が IHRpCL の最大值よりも小 となった。したがって，I 群においては A 静注開始後 5 分で全例の CL が IHRpCL の最大值より小となり, II群との判別が可能であった。

II 群のうち, IIY 群では静注開始後 30 秒および 60 秒 のCL は BCL との間に有意差がなかったが, 90 秒, 120 秒ならびに 5 分後に有意差が生じた. IIE 群でも同様 に静注開始後 120 秒および 5 分後に有意差が生じた(い ずれも $\mathrm{p}<0.01$ ).

IIY 群と IIE 群との間に, BCL 測定時から A 静注開 始後 120 秒までは有意差がなかったが， 5 分ではIIY 群は IIE 群よりも有意に小となった $(\mathrm{p}<0.05)$. IIY 群 では静注開始後 120 秒では 2 例, 5 分後でも 1 例の $\mathrm{CL}$ が IHRpCL の最大值より大であったＩIE 群では静注 開始後 120 秒および 5 分後においても 1 例の CL が IHRpCL の最大值より大であった。

$\mathrm{A}$ 静注終了 5 分後の CL は IY 群は IIY 群より, IE 群は IIE 群より有意に小であった（それぞれ $\mathrm{p}<0.05$, $\mathrm{p}<0.01$, 表 2$). \mathrm{BCL}$ との比較において, A 静注によ る $\mathrm{CL}$ の短縮率 $[(\mathrm{BCL}-\mathrm{A}$ 静注 5 分後の $\mathrm{CL}) / \mathrm{BCL}]$ は, IY 群 $40.5 \%$, IE 群 $31.3 \%$, IIY 群 $47.8 \%$, IIE 群 25\%であり，Y 群において CL の短縮が大きい傾向が みられた. BCL の延長は IIY 群にのみ認められたこと より, IIY 群は安静時に副交感神経による negative chronotropyを最も強く受けていると考えられた。

4） P 静注過程における CL は，I群のうち，IY 群で は A 静注開始 5 分より引き続き全例において IHRpCL の最大值よりも小であり, IHRo 決定時には, IY 群 の $\mathrm{CL}$ の平均値は IHRpCL の最大値の平均値よりも 

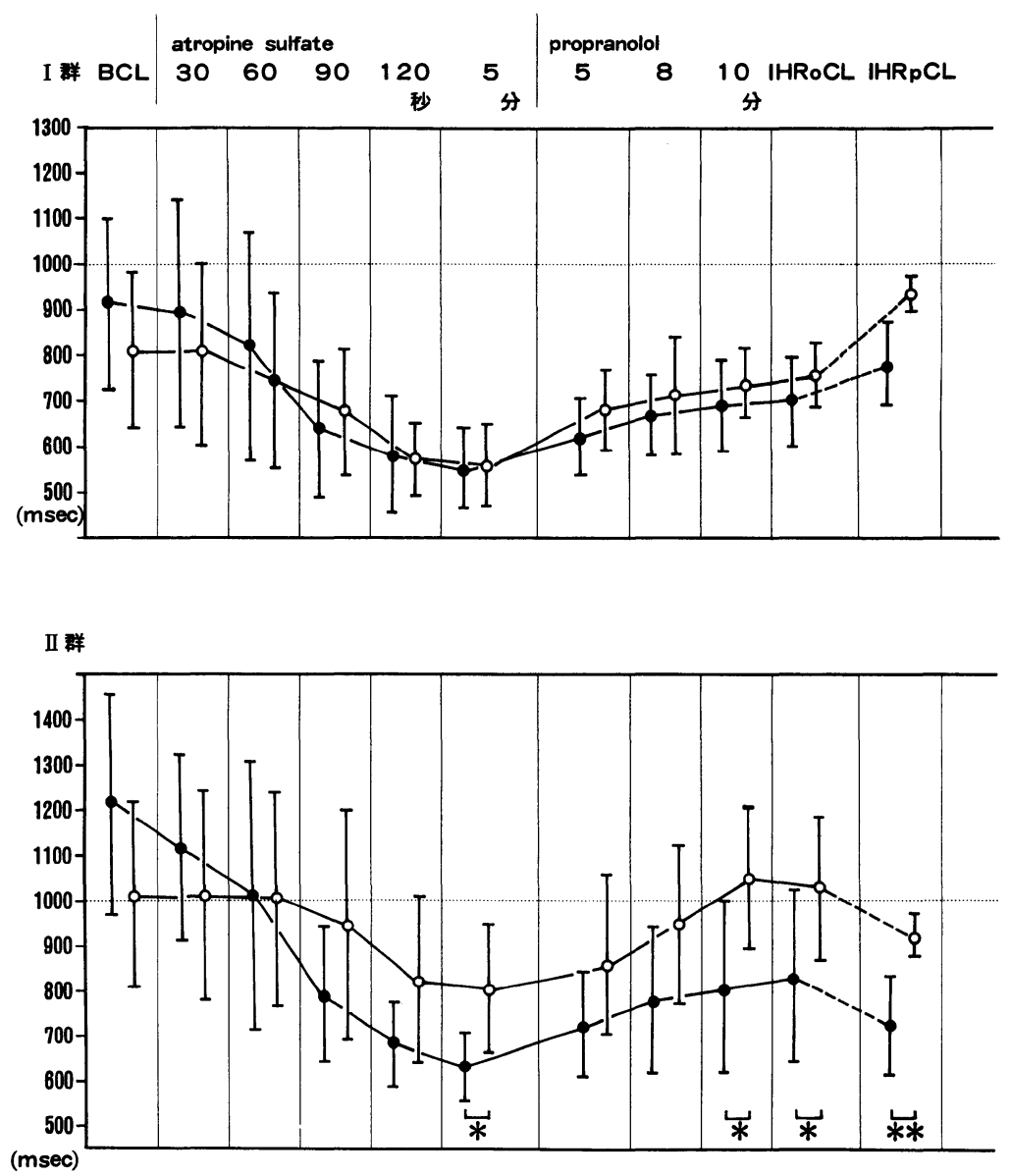

I Y vs I E, II Y vs IIE; $* p<0.05, * * p<0.01$

- Y群, OE群

図 1 TAB の全経過における IY と IE 拈よび IIY と IIE の洞周期の変動

表 $1 \mathrm{TAB}$ の全過程における CL と IHRpCL との関係に対応する症例数

\begin{tabular}{|c|c|c|c|c|c|c|c|c|c|c|c|c|}
\hline & & & \multicolumn{6}{|c|}{ atropine sulfate } & \multicolumn{4}{|c|}{ propranolol } \\
\hline & & & 測定時 & 30 & 60 & 90 & 120秒 & 5 分 & 5 & 8 & 10 分 & $\begin{array}{c}\text { IHRoCL } \\
\text { 測定時 }\end{array}$ \\
\hline \multirow{4}{*}{ I } & \multirow{2}{*}{ I Y } & $\mathrm{CL}<\mathrm{IHRpCL}$ & 2 & 3 & 5 & 11 & 12 & 14 & 12 & 13 & 13 & 14 \\
\hline & & $\mathrm{CL}>\mathrm{IHRpCL}$ & 12 & 11 & 9 & 2 & 2 & 0 & 0 & 0 & 0 & 0 \\
\hline & \multirow{2}{*}{$\mathrm{I} \mathrm{E}$} & $\mathrm{CL}<\mathrm{IHRpCL}$ & 6 & 4 & 5 & 4 & 7 & 7 & 7 & 6 & 5 & 7 \\
\hline & & $\mathrm{CL}>\mathrm{IHRpCL}$ & 1 & 1 & 1 & 1 & 0 & 0 & 0 & 0 & 0 & 0 \\
\hline \multirow{4}{*}{ II } & \multirow{2}{*}{ II Y } & $\mathrm{CL}<\mathrm{IHRpCL}$ & 0 & 0 & 2 & 3 & 6 & 7 & 5 & 2 & 0 & 0 \\
\hline & & $\mathrm{CL}>\mathrm{IHRpCL}$ & 8 & 8 & 6 & 5 & 2 & 1 & 3 & 6 & 8 & 8 \\
\hline & \multirow{2}{*}{ II $\mathrm{E}$} & $\mathrm{CL}<\mathrm{IHRpCL}$ & 1 & 2 & 2 & 3 & 5 & 5 & 3 & 3 & 0 & 0 \\
\hline & & $\mathrm{CL}>\mathrm{IHRpCL}$ & 5 & 4 & 4 & 3 & 1 & 1 & 2 & 3 & 5 & 6 \\
\hline
\end{tabular}


表 $2 \mathrm{BCL}$ 測定時, $\mathrm{A}$ 静注後 5 分, IHRoCL 測定時 の洞周期における I Y と II Y および I E と II E の関係

\begin{tabular}{c|c|c|c}
\hline & $\begin{array}{c}\mathrm{BCL} \\
\text { 測定時 }\end{array}$ & $\begin{array}{c}\mathrm{A} \text { 静注後 } \\
5 \text { 分 }\end{array}$ & $\begin{array}{c}\text { IHRoCL } \\
\text { 測定時 }\end{array}$ \\
\hline $\mathrm{Y}$ & $\begin{array}{c}\text { I } \mathrm{Y}<\text { II Y } \\
\mathrm{p}<0.01\end{array}$ & $\begin{array}{c}\text { I } \mathrm{Y}<\text { II Y } \\
\mathrm{p}<0.01\end{array}$ & $\mathrm{NS}$ \\
\hline $\mathrm{E}$ & $\begin{array}{c}\text { I } \mathrm{E}<\text { II E } \\
\mathrm{p}<0.05\end{array}$ & $\begin{array}{c}\text { I } \mathrm{E}<\text { II E } \\
\mathrm{p}<0.01\end{array}$ & $\begin{array}{c}\text { I } \mathrm{E}<\text { II E } \\
\mathrm{p}<0.01\end{array}$ \\
\hline
\end{tabular}

有意に小であった $(\mathrm{p}<0.05) . \mathrm{IE}$ 群においても A 静注 開始後 120 秒， 5 分に引き続き全例において，CL は IHRpCL の最大值よりも小であり, IHRo 決定時の $\mathrm{CL}$ (IHRoCL) の平均値は IHRpCL の最大值の平均値 よりも有意に小であった $(\mathrm{p}<0.001)$.

IY 群と IE 群の比較に打いては, P 静注過程ならび にIHRo 決定時のいずれの時点においても有意差は 認められなかった。

II 群では, IIY 群の CL の平均値は IHRpCL の最大 值の平均値との比較に打いて, A 静注開始後 120 秒, 5 分では小であったが, P 静注開始後より IHRo 決定時 に至るまでに大となった。しかし P 静注過程のいずれ の時点においても有意差は認められなかった。 IIE 群 では $\mathrm{A}$ 静注開始後 120 秒, 5 分および $\mathrm{P}$ 静注開始後 5 分には CL の平均值が IHRpCL の最大值の平均値よ りも小であり， 8 分後より IHRo 決定時に至るまでに 大となったが有意差は認められなかった。

IIY 群と IIE 群との比較においては，A 静注開始後 5 分では, IIY 群の CL の平均值は II E 群よりも有意 に小であり,この傾向は $\mathrm{P}$ 静注開始後も継続したが, 5 分と 8 分では有意差が認められず，10分と IHRo 決 定時においては, IIY 群はIIE 群よりも有意に小と なった（いずれす $\mathrm{p}<0.05 ）$.

IIY 群においては, P 静注開始後 5 分で 5 例, 8 分で も 2 例の CL が IHRpCL の最大值よりも小であり, 10 分に至って全例の CL が IHRpCL の最大值よりも大 となった．IIE 群においては，5分と 8 分では 3 例の CL が IHRpCL の最大值よりも小であり，10分に至っ て全例の CL が IHRpCL よりも大となった。 ほぼ全例 のIHRoが10分から12分で記録されており，したがっ て, TAB の過程でII群が判別されるためには体重よ り計算した $\mathrm{P} の$ 全量を静注する必要があった.

$\mathrm{A}$ 静注終了後 5 分の CL との比較において, IHRo 決定時の $\mathrm{CL}$ の変化率 $[(\mathrm{IHRoCL}-\mathrm{A}$ 静注終了後 5 分 の CL)/A 静注終了後 5 分の CL) は IY 群 $27.4 \%$, IE
群 $34.4 \%$, IIY 群 $29.0 \%$, IIE 群27.0\%であり, IE 群で わずかに大きい傾向が認められた。

\section{考察}

正常洞結節機能を有する健常者においては，TAB 後の固有心拍数は加齢に伴い減少する ${ }^{6)}$.一方, 健常者 の心拍数は加齢に伴い減少するという報告7と加龄に 伴う有意の変化はないとの報告 ${ }^{33899) か ゙ あ る . ~}$

洞結節機能と加蹂について, Arguss ら $5^{71}$ は, 高齢者 における洞性徐脈の原因として, 副交感神経緊張のえ 進を想定している。一方, Pfeifer ら ${ }^{10)}$ と久賀ら ${ }^{11}$ は, 加齢に伴い心血管系に対する交感神経活動は増加し， 副交感神経活動は減少すると報告している. 正常洞結 節に打いては，加齢に伴い洞結節細胞は減少し，結合 組織成分は増加することが報告されており ${ }^{12)}$, SSS に おいても，正常洞結節に打けるものと同様の加齢によ る変化が認められる ${ }^{13)}$.

Yamaguchi ら ${ }^{14)}$ および久賀ら ${ }^{15)}$ はSSS における内 因性洞結節機能障害は進行性に増悪することを報告し ており，SSSに扮いて，進行性の内因性洞結節細胞障 害ならびに洞結節機能に対する最も重要な外因性要因 である自律神経機能の加齢による变化を知ることは, SSS の病態生理と予後の予知の上で重要である.

本研究においては, SSS 症例をTABにより正常 IHRo 群と異常 IHRo 群とに分類し, 高齢者群ならび に非高齢者群に対して，A 静注と引き続き $\mathrm{P}$ 静注を行 らことにより, 正常 IHRo 群と異常 IHRo 群との間 の，1）加齢による変化と，2）自律神経の影響に打け る差異について評価した。

心臟の自動能，収縮性および伝導性は自律神経系の 影響を受ける。この複雑性の原因は，交感神経と副交 感神経の二重神経支配に起因すると考えられ，さらに それぞれが中枢神経系と末梢神経系の双方に扮いて相 互の関与があることによる ${ }^{16)}$.したがって, 自律神経の 心臓に対する作用は，交感神経と副交感神経の作用の 代数的加算ではあり敩ない16).

薬理学的自律神経遮断において, 交感神経と副交感 神経を，PとAによって，扔の扔の独立して完全に遮 断することは困難である。しかし，本法に対するSSS の各群の反応には有意差が認められ, 本研究の結果よ り各群の特性を明らかにすることは可能であると考え られた。一方，本法により求められる IHRo は再現性 に優れ ${ }^{17)}, \mathrm{SSS}$ の病態ならびに予後の予知についての 有用性は多くの報告者により確認されている ${ }^{17) ~ 21) . ~}$ 
BCLについては, 被検者は電気生理学的検査室にお ける緊張状態にあると想像され，多くは自律神経によ る positive chronotropyを受けていると考えられる。 II 群の BCL は，Y 群ならびに $\mathrm{E}$ 群のいずれにおいて も，I群よりも有意に延長しており，自律神経の影響の もとでも，II群における内因性洞結節機能の障害の強 さが示唆された。

A 静注による CL の変動について, Alboni ら ${ }^{22)}$ は A $0.04 \mathrm{mg} / \mathrm{kg}$ 静注後の心拍数が $\mathrm{IHRp}$ より小であると き洞結節機能の内因性異常が示唆されることを報告 し, P の使用が禁忌の症例の洞結節機能異常の確認は, $\mathrm{A}$ のみで可能であると考えた。本研究では，A 静注後 の CL が IHRpCL より大であることはII 群において 特異的であったが，一方，A 静注のみではII 群の一部 の症例が正常と判定される可能性が示唆された.

$\mathrm{A}$ 静注後の CL の短縮率は $\mathrm{Y}$ 群において大である ことにより，Y 群では副交感神経の影響が強く，また BCL の延長が IIY 群に扮いての及認められたことよ り, IIY 群は副交感神経による negative chronotropy を最も強く受けていると考兄られた。

I 群においては Y 群と $\mathrm{E}$ 群の間に有意差がなく,一 方, 内因性の洞結節機能障害を有すると考えられる II 群に打いて，Y 群と $\mathrm{E}$ 群との間に有意差が認められる 結果となった。I群においては，II群よりも標準偏差 は小であり，有意差が認められなかった原因は標準偏 差にはないと考觉られた。

$\mathrm{P}$ 静注による CL の変動については, I 群では, A 静 注後に引き続き IHRo 決定時に至るまでの全例の CL が IHRpCL の最大值よりも小であり，I 群における障 害は主として副交感神経の異常な過緊張による，もので あり，内因性洞結節機能は正常であることが確認され た. II群に打いては，A 静注により CL は短縮し， 2 例 のみを除いて IHRpCL の最大值よりも小となったが, $\mathrm{P}$ 静注開始後より CL は延長し IHRpCL の最大値よ りも大となった。即ち， I 群においては， $\mathrm{P}$ 静注前後 の CL の変動はいずれも正常 $\mathrm{CL}$ 範囲内の変化であっ たが, II 群においては, 交感神経による positive chronotropy 作用はCL の正常値上限の境界領域で critical な要因であると考兄られた。同時に, 結果 4) に示された如く，II群の内因性洞結節機能障害を顕性 化させるためには, 体重より計算された $\mathrm{P}$ の全量の静 注が必要であった. Kontani ら ${ }^{23)}$ は, SSS 症例のらち $\mathrm{A}$ 群に対する心拍数増加が十分でない群の中で， $\mathrm{P}$ に よる心拍数の減少が大きい群とそれ以外の群とを分類
したが，本研究においては $\mathrm{P}$ に対する反応において， 各群間に有意差は認められなかった。

\section{結論}

1）異常 IHRo 群では正常IHRo との比較におい て，BCL の有意な延長があり，自律神経によって代償 されえない洞結節機能障害の存在が示唆された。

2） A 静注後の CL が IHRoの最大值よりも大であ ることは異常 IHRo 群に特異的であるが, 一方, A 静 注のみでは異常 IHRo 群の一部が正常と判定される 可能性がある。

3）異常 IHRo 群ならびに正常 IHRo 群において, 非高齢者群は副交感神経優位の傾向を示し, 特に異常 IHRo を示す非高柃者群においては副交感神経による negative chronotropyを最も強く受けていると考克 られる。

4）A 静注後からIHRo 決定時に至る過程におい て, 正常 IHRo には年䟥による差異は認められなかっ たが, 異常 IHRo 群では高歯者群において, CL の有意 の延長が認められた。

5） P 静注に対する反応において，異常 IHRo 群と 正常 IHRo 群の間に差異は認められなかった。一方, 異常IHRo 群においては，交感神経による positive chronotropy はCL の正常上限境界における critical な要因と考兄られた。

\section{文献}

1) Jordan JL, Yamaguchi I, Mandel WJ : Studies on the mechanisms of sinus node dysfunction in the sick sinus syndrome. Circulation $57: 217$ $-223,1978$.

2) Treese $N$, Steppert $C$, Kasper $W$, Meinertz $T$, Pop T, Meyer J: Die funktionelle autonome Blockade in der Diagnostik der Sinus-knotenfunktionsstoerungen. Dtsch Med Wschr 109 : 87-91, 1984.

3) Marneffe MD, Jacobs P, Melot C, Englert M : Autonomic nervous system and sinus node function through out life. (Abstract). International Symposium on Cardiac Arrhythmias 65 (Kanazawa 1986)

4) Vallin HO: Autonomous influence on sinus node and AV node function in the elderly without significant heart disease: Assessment with electrophysiological and autonomic tests. 
Cardiovasc Res 14:206-216, 1980.

5) Kuga K, Yamaguchi I, Sugishita Y, Ito I : Assessment by autonomic blockade of agerelated changes of the sinus node function and autonomic regulation in sick sinus syndrome. Am J Cardiol $61: 361-366,1988$.

6) Jose $\mathrm{AD}$, Collison $\mathrm{D}$ : The normal range and determinants of the intrinsic heart rate in man. Cardiovasc Res $4: 160-167,1970$.

7) Arguss N, Rosin E, Adolph RJ, Fowler NO: Significance of chronic sinus bradycardia in elderly people. Circulation 46:924-930, 1972.

8) Sato I, Hasegawa Y, Takahashi N, Hirata Y, Shimomura K, Hotta K: Age-related changes of cardiac control function in man. J Gerontol $36: 564-572,1981$.

9) Kostis JB, Moreyra AE, Amendo MT, Pietro JD, Cosgrove N, Kuo PT : The effect of age on heart rate in subjects free of heart disease. Circulation $65: 141-145,1982$

10) Pfeifer MA, Weinberg CR, Cook D, Best JD, Reenan A, Halter JB: Differential changes of autonomic nervous system function with age in man. Am J Med $75: 249-258,1983$.

11）久賀圭䘠, 山口 嚴, 杉下靖郎, 伊藤 㦑: 洞不全 症候群と年齢。心臓ペーシング $3: 349-354$, 1987.

12) Truex RC: The sinoatrial node and its connection with the atrial tissue. In: The Conduction System of the Heart. Structure, Function snd Clinical Implications. Wellens HJJ, Lie KI and Janes MJ (ed), Lea and Febiger, 1976, 209 -226 .

13) Sugiura M, Ohkawa S, Hiraoka K, Okimoto T, Ueda $\mathrm{K}$, Shimada $\mathrm{H}$, Matsuo $\mathrm{H}$ : A clinicopathological study on the sick sinus syndrome. Jpn Heart J 17 : 731-741, 1976.

14) Yamaguchi I, Kurusu T, Togo T, Iida K, Sugishita Y, Ito I: Follow-up study of patients with sick sinus syndrome by pharmacologic total autonomic blockade (Abstr). JACC 3 : 517, 1984.

15）久賀圭祐, 山口 篇, 来栖武雄, 東郷利人, 野口祐 一, 富沢巧治, 杉下靖郎, 伊藤 嚴：老年者の洞結 節機能の予後に関する検討 (抄録). 日本老年医学 会雑誌 $22: 286,1985$.

16) Levy MN : Sympathetic-parasympathetic interactions in the heart. Circ Res $29: 437-$ $445,1971$.

17）山口 嚴, 来栖武雄: 洞不全症候群における自律 神経の関与と人工ペースメーカーの適応. 日本臨 床 $43: 36-41,1985$.

18) Kang PS, Gomes JAC, Kelen G, EL-Sherif N : Role of autonomic regulatory mechanisms in sinoatrial conduction and sinus node automaticity in sick sinus syndrome. Circulation $64: 832-838,1981$.

19) Desai JM, Sheinman MM, Strauss HC, Massie B, O'Young J: Electrophysiologic effects of combined autonomic blockade in patients with sinus node disease. Circulation $63: 653-960$, 1981.

20）山口 晟, 東郷利人, 杉下靖郎, 伊藤 㦑 : 洞結節 機能評価法に関する臨床的検討。心藏 $13: 929$ -936, 1981.

21) Kang PS, Gomes JAS, EL-Sherif N : Differential effects of functional autonomic blockade on the variables of sinus nodal automaticity in sick sinus syndrome. Am J Cardiol $49: 273-282,1982$.

22) Alboni P, Malcarne C, Pedroni P, Masoni A, Narula OS: Electrophysiology of normal sinus node with and without autonomic blockade. Circulation $65: 1236-1242,1982$.

23) Kontani K, Matsushita S, Matsunuma K, Ikeda $T$, Inasaka $T$ : Altered autonomic mechanisms in the sick sinus syndrome amd diurnal variations in the parameters of sinus node function. Jpn Circ J 44 : 518-530, 1980. 


\title{
Abstract \\ The Heart Rate Alternative Sequence During Pharmacologic Total Autonomic Blockade in Patients with Sick Sinus Syndrome: Differential Effects in Relation to Age
}

\author{
Akihiko Miyamoto, Iwao Yamaguchi, Keisuke Kuga, Yasuro Sugishita and Iwao Ito
}

To study the age-relatd changes of the sinus node function and the variations of influence of autonomic nervous system, pharmacologic total autonomic blockade (TAB) was conducted in 35 patietns with symptomatic sinus bradycardia (21 men and 14 women, $50 \pm 21$ years, mean $\pm \mathrm{SD}$ ). Twenty-one patients [Group I, consisting of 14 patients younger than 60 years (group IY) nd 7 patients 60 years or older (grop IE)] had a normal intrinsic heart rate (IHRo), and 14 patients had an abnormal IHRo [Group II, consisting of 8 patietns younger than 60 years (group IIY) and 5 patients 60 years or older (group IIE)]. The basic cycle length was significantly longer in group II than in group I, suggesting that intrinsic sinus node function was more seriously deteriorated in group II in spite of the compensatory effect of autonomic regulation. In group II it was characteristic that the cycle length (CL) after atropine

Division of Cardiology, Department of Internal Medicine, Institute of Clinical Medicine, University of Tsukuba sulfate administration was longer than the $\mathrm{CL}$ of the predicted intrinsic heart rate (IHRp). Otherwise, some group II patients might be regarded as normal by atropine sulfate administration alone. Parasympathetic tone showed a negative correlation with age, and it was most enhanced in group IIY, suggesting that parasympathetic negative chronotropy was stronger in this group. In the course of propranolol administration, prolongation of CL was significantly larger in group IIE than in group IIY, but there was no age-related difference in group I. In group II, beta-adrenergic blockade with propranolol administration showed that sympathetic positive chronotropy was a critical compensatory factor around the upper limit of the CL of IHRp. In conclusion, aging plays an important role for heart rate alteration during $\mathrm{TAB}$, which depends upon the pathogenesis of the sick sinus syndrome.

key words: sick sinus syndrome, pharmacologic total autonomic blockade, aging

(Jpn J Geriat 26: 272-278, 1989) 